\title{
MODERN CIVILIZATION: SIMILARITIES AND DIFFERENCES
}

\author{
Ochilova Nigora Ruzimuratovna \\ Associate professor of the department "Social sciences", Karshi Engineering-Economics Institute, \\ Uzbekistan, Karshi city
}

Article DOI: https://doi.org/10.36713/epra5472

\begin{abstract}
The urgency of this problem lies in the fact that the process of globalization, which is a characteristic feature of modern civilization, has also exacerbated the conflict between East and West. By now, the Western world can set prices for these types of goods, spreading information technology around the world, making them an important component of modern production. As a result, the gap between developed and developing countries is widening. Any attempt by developing countries to "catch up" ends with temporary success.
\end{abstract}

KEYWORDS: new technical means, world economy, changes, social production, information society, members of society, strengthening social ties, new phenomena, foreign investment, capital and goods.

\section{DISCUSSION}

Modern Eastern and Western civilizations are much more complex. Of course, the image of both has changed radically since the nineteenth century. The changes that have taken place in the West over the past thirty years deserve special attention. In particular, although the process of industrialization in the early stages put the workers in a miserable position, in our time it has provided material well-being for almost all citizens of developed countries. About 80 percent of US citizens are now members of collective capital. About seventy percent of employees use social funds more when they provide less to the community, and as a result they get used to living at the expense of society in part. [1.s -123].

A similar situation is observed in most developed countries of the Eastern world (Turkey, South Korea, Saudi Arabia, China, Kuwait, etc.). Material well-being is, of course, primarily a product of economic growth. Thus, significant changes in the economic structure of the world economy are still ongoing. Today he rises to the absolute level of the manager of transnational corporations. Academician N. According to Moiseev, transnational corporations account for $30 \%$ of world production assets, $80 \%$ of trade in high technologies and $90 \%$ of capital exported from developed countries [2.c-12].

As a result of such changes in the production system, the class of managers and technocrats, their ideological leaders, are immersed in the dream of total rule over the whole world. It is well known that powerful civilizations and empires dream of ruling the world at the end of their lives, and that these dreams will shape civilizations and empires. The fact that these dreams are being reborn is a sign that the West is in a systemic crisis.

Fundamental changes in the structure of the economy demanded from the world economy to intensify investment activity, introduce new technologies in production, invest heavily in modern technologies, take measures to save energy and restructure the energy complex. To accomplish such tasks, it was necessary to carry out research work of practical importance. For this reason, during the twentieth century, special attention was paid to the development of science and technology in developed countries. As a result, the range of power used in human practice has expanded. For example, man, on the one hand, managed to create devices capable of transmitting the weakest signal with a power of 


\section{EPRA International Journal of Research and Development (IJRD)}

$0.1 \times 10-18$ watts. On the other hand, he built a spacepowered hydrogen bomb. [3.c -4].

Such progress in science and technology, the rapid penetration of its achievements into the branches of the national economy led to the automation of production. In many scientific sources, the automation process is combined with the autonomy of production. Not really. Automation is the process of increasing the efficiency of the social production process, the introduction of technical means that allow the efficient use of various raw materials and materials. Any automation system includes two subsystems. One of them consists of technical units (machines), and the other is an operator (person).

Advances in science and technology have paved the way for the dissemination of scientific information. In 1860-1960 alone, more than 6 million scientific publications in natural sciences were created. It is noteworthy that half of these publications were published in 1946-1960. [4.c -41] .. It is clear that by the first half of the twentieth century, the amount of scientific information began to increase geometrically. In the first half of the twentieth century, the volume of scientific information doubled every 13.5 years, but by the beginning of the twentyfirst century it will increase by 100 percent every $2-3$ years [5.c-242].

Such advances in science and technology led to the creation of the information society in the West towards the end of the twentieth century. At the present stage of development of modern Western civilization, information has become not just information or knowledge, but a quantitative norm that allows you to manage a particular system, as well as a strategic and geopolitical resource. For example, today 40 percent of US GDP falls on the information production sector [6.].

Such a development of events, according to Microsoft President B. Gates, in the opinion of this led to a rational organization of economic activity and, ultimately, to an increase in the standard of living of people. [7].

It is this information that ensures that Western countries are at the forefront of civilized development.

The main features of the information society in the West are:

- Production, operation and popularity of modern information technologies;

- Opportunities for members of society and social groups to receive the necessary information and knowledge at any time and anywhere;

- the presence of a developed infrastructure capable of creating national information resources, the amount of information required to accelerate scientific, technological and socio-historical processes;
- Fast automation and robotization of management and production;

- sharp changes in social structures and, as a result, the expansion of information activities and services;

- Decrease in the number of people employed in traditional industries with an increase in labor productivity.

Even today, the developed countries of the West pay special attention to the transition to the information society. Corresponding strategic programs have even been developed on this score. For example, in the European Union, which unites 27 countries of the ancient continent, in 1994 a special action plan was developed "[8.c-11].

The growth of material well-being has exacerbated demographic processes in both the West and the East. It is known that the larger the material process in society, the lower the rate of demographic growth and, conversely, the lower the level of material wellbeing, the higher the rate of demographic growth. This law is evident in the Western world. P. Buchanan writes: The West is literally "dying": the population of almost all Western countries is shrinking at an incredible rate. We have never faced such a dangerous threat since the Black Plague, which wiped out a third of Europe's population in the fourteenth century. There is no doubt that this catastrophe will destroy the entire Western civilization.

\section{LIST OF USED LITERATURE}

1. Valtukh K.K. Impossibility theorems // Social sciences and modernity. - 1994. - No. 1 - P.123.

2. Moiseev N.N. With thoughts about the future of Russia .- M .: Fund for Assistance to Social Development. and polit. Sciences, 1997.- S. 12.

3. Choriev S. Ideological image of the modern world. - T.: The world of creation, 2003. - 4-p.

4. Chemiris A.T. The ratio of social and scientific and technological progress. // Scientific and technological revolution and social progress. - $M$ $\therefore$ 1969.S. 41.

5. Bernal J.D. The Social Function of Science.-L .: 1939. P.242.

6. Yakovets Yu.V. History of Civilizations. - M .: ICF, 1997

7. Gates B Road to the future.- Moscow: RSL, 1996

8. Yokubov S. Information Society: Not Fiction, But Reality. // Tafakkur.-2007.- No. 4.- 11p.http://www.edoctor.uz/page/news/uzbekistan/22 19 ? print $=$ print .

1. 10.www.ecsocman.edu.ru/images/pubs/2004/04/0 3/0000153589/012iONOW.pdf

2. 11.www.nsu.ru/filf/rpha/papers/civ/wilkinsn.htm $-114 k$

3. 12 .

www.ecsocman.edu.ru/images/pubs/2004/04/03/0 000153589/012iONOW.pdf 